\title{
Analysis of variable-base heating and cooling degree-days for Turkey
}

\author{
Orhan Büyükalaca*, Hüsamettin Bulut, Tuncay Yılmaz \\ Department of Mechanical Engineering, University of Cukurova, 01330 Adana, Turkey
}

Received 16 January 2001; accepted 12 February 2001

\begin{abstract}
The degree-day method is one of the well-known and the simplest methods used in the Heating, Ventilating and Air-Conditioning industry to estimate heating and cooling energy requirements. In this study, the heating and cooling degree-days for Turkey are determined by using long-term recent measured data. Five different base temperatures ranging from 14 to $22^{\circ} \mathrm{C}$ are chosen in the calculation of heating degree-days. In the case of cooling degree-days, 6 different base temperatures in the range 18 to $28^{\circ} \mathrm{C}$ are used. Yearly heating and cooling degree-days are given both in tabular form and as counter maps for all the provinces of Turkey (78 weather stations). (C) 2001 Elsevier Science Ltd. All rights reserved.
\end{abstract}

Keywords: Heating degree-day; Cooling degree-day; Turkey; Energy analysis

\section{Introduction}

Energy analysis plays an important role in developing an optimum and cost effective design of HVAC system for a building. Although there are different energy analysis methods, which vary in complexity, the degree-day methods are the simplest methods and well-established tools for energy analysis if the buildings use, the efficiency of HVAC equipment, indoor temperature and internal gains are relatively constant. The value of degree-days is a measure used to indicate the demand for energy to heat or cool buildings. The monthly and/or annual cooling and heating requirements of specific buildings in different locations can be estimated by means of the degree-days concept. The method assumes that the energy needs for a building

\footnotetext{
* Corresponding author. Tel.: +90-322-3386485; fax: +90-322-3386126.

E-mail address: orhan1@mail.cu.edu.tr (O. Büyükalaca).
} 
are proportional to the difference between the mean daily temperature and a base temperature. The base temperature is the outdoor temperature below or above which heating or cooling is needed [1,2]. In terms of degree-days, the annual energy consumption, $Q_{\text {year }}[$ W.day] can be calculated as [1];

$$
Q_{\text {year }}=\frac{K_{\text {tot }}}{\eta} D D
$$

where $K_{\text {tot }}$ is the total heat-transfer coefficient of the building in $\mathrm{W} /{ }^{\circ} \mathrm{C}, \eta$ is the efficiency of the heating or cooling system and $D D$ is the value of degree-days for heating or cooling. For heating, heating degree-days (HDD) can be determined using following expression;

$$
\mathrm{HDD}=(1 \text { day }) \sum_{\text {days }}\left(T_{\mathrm{b}}-T_{\mathrm{m}}\right)^{+}
$$

in which, $T_{\mathrm{b}}$ is the base temperature and $T_{\mathrm{m}}$ is the daily mean outdoor temperature. Cooling degree-days (CDD) can be calculated in a manner analogous to that for heating degree-days;

$$
\mathrm{CDD}=(1 \text { day }) \sum_{\text {days }}\left(T_{\mathrm{m}}-T_{\mathrm{b}}\right)^{+}
$$

The plus signs above the parentheses of Eqs. (2) and (3) indicate that only positive values are to be counted. Using HDD and CDD, the annual heating consumption, $Q_{\mathrm{h}}$, and the annual cooling requirements, $Q_{\mathrm{c}}$, in terms of $\mathrm{kWh}$ can be calculated, respectively as;

$$
\begin{aligned}
& Q_{\mathrm{h}}=\frac{K_{\mathrm{tot}}}{\eta} \operatorname{HDD} \frac{24}{1000} \\
& Q_{\mathrm{c}}=\frac{K_{\mathrm{tot}}}{\eta} \operatorname{CDD} \frac{24}{1000}
\end{aligned}
$$

Traditionally, heating degree-days are calculated at a base temperature of $18^{\circ} \mathrm{C}$ (or $65^{\circ} \mathrm{F}$ ) and cooling degree-days are determined at a base temperature of $22^{\circ} \mathrm{C}$ $\left(71.6^{\circ} \mathrm{F}\right)$ for a typical uninsulated building. However, the average value of $T_{\mathrm{b}}$ varies widely from one building to another, because of widely differing personal preferences for the settings of thermostat and of the thermostat setback and because of different building characteristics such as thermal insulation, air leakage and solar gains. Hence degree-days with a base temperature of $18^{\circ} \mathrm{C}$ in heating or $22^{\circ} \mathrm{C}$ in cooling must be employed with caution [3].

The traditionally-used base temperatures have been questioned by a number of authors. Said [2] found that a heating base temperature in the range of 18 to $21^{\circ} \mathrm{C}$ is 
suitable in Saudi Arabia depending upon the insulation level. The recommended cooling base temperature is between 23 and $25.5^{\circ} \mathrm{C}$ for buildings without insulation and between 25.5 and $27.8^{\circ} \mathrm{C}$ for well-insulated buildings. Kodah and El-Shaawari [4] recommended that a heating base-temperature of $15.5^{\circ} \mathrm{C}\left(60^{\circ} \mathrm{F}\right)$ in Jordan is appropriate. Badescu and Zamfir [5] reported that a $18^{\circ} \mathrm{C}$ base temperature for heating degree-day calculations is appropriate for living rooms and bedrooms in Romania.

Although analysis of weather data for design of HVAC systems and energy consumption calculations has been completed several years ago for developed countries, this subject has been considered seriously only in recent years in Turkey. The weather data studies in Turkey have been initiated with the construction of modern commercial and domestic buildings, the start of natural gas usage and because of a possible energy crisis. Although some independent studies [6-10] have been performed in recent years to compile weather data, well-established and reliable databases that can be used directly by designers and energy managers still do not exist. Not all of the cities of Turkey were considered in existing studies, and in some studies, the results were based on the data obtained during a short-period of time (only a few years) or the data measured in recent years were not used. In some studies, the results were presented only for one base temperature.

The need to fill the gap in weather data for Turkey provided the stimulus for this project that includes the production of design data, degree-days and bin data for heating and cooling and solar radiation. In this paper, the results of the degree-day studies are reported.

\section{Database for temperature}

Accurate and reliable weather data are crucial for building energy simulations and analyses. The weather data being used in energy analysis determines the accuracy and characteristics of the results. Therefore, the database used in an energy analysis should cover a long period and depend on recent values [1]. In this study, daily minimum and maximum outdoor dry-bulb temperatures of recent years were used. The data obtained during at least 14 years (except for Eskişehir) were used in the calculations. Daily mean temperatures were obtained by averaging the minimum and the maximum temperatures. The raw data were taken from The State Meteorological Affairs General Directorate (DMI) on magnetic disks for 78 provinces. Information for the weather stations and periods of the data considered are given in Table 1.

\section{Results and discussion}

Based on the database for temperature shown in Table 1 and using Eqs. (2) and (3), annual heating and cooling degree-days for various base temperatures were obtained for each province. 
Table 1

Information for the provinces considered in the study

\begin{tabular}{|c|c|c|c|c|c|}
\hline Location & Longitude & Latitude & Elevation (m) & Period & Total years \\
\hline Adana & 35.18 & 36.59 & 20 & 1981-1996 & 16 \\
\hline Adapazarı & 30.25 & 40.47 & 30 & 1982-1998 & 17 \\
\hline Adiyaman & 38.17 & 37.45 & 678 & 1981-1998 & 18 \\
\hline Afyon & 30.32 & 38.45 & 1034 & 1981-1998 & 18 \\
\hline Ağr1 & 43.08 & 39.31 & 1585 & 1981-1998 & 18 \\
\hline Aksaray & 34.03 & 38.23 & 980 & 1981-1998 & 18 \\
\hline Amasya & 35.51 & 40.39 & 412 & 1981-1998 & 18 \\
\hline Ankara & 32.53 & 39.57 & 894 & 1981-1995 & 15 \\
\hline Antalya & 30.42 & 36.53 & 42 & $1981-1995$ & 15 \\
\hline Ardahan & 42.42 & 41.08 & 1829 & 1981-1998 & 18 \\
\hline Artvin & 41.49 & 41.10 & 597 & 1981-1998 & 18 \\
\hline Aydın & 27.50 & 37.51 & 57 & 1983-1998 & 16 \\
\hline Balıkesir & 27.52 & 39.39 & 147 & 1983-1997 & 15 \\
\hline Bartın & 32.21 & 41.38 & 30 & 1981-1998 & 18 \\
\hline Batman & 41.10 & 37.52 & 540 & 1983-1998 & 16 \\
\hline Bayburt & 40.15 & 40.16 & 1550 & 1981-1998 & 18 \\
\hline Bilecik & 29.58 & 40.09 & 526 & 1981-1998 & 18 \\
\hline Bingöl & 40.30 & 38.52 & 1177 & 1981-1998 & 17 \\
\hline Bitlis & 42.06 & 38.22 & 1559 & 1981-1998 & 18 \\
\hline Bolu & 31.36 & 40.44 & 742 & 1981-1998 & 18 \\
\hline Burdur & 30.20 & 37.40 & 967 & 1981-1998 & 18 \\
\hline Bursa & 29.04 & 40.11 & 100 & 1983-1998 & 16 \\
\hline Çanakkale & 26.24 & 40.08 & 3 & 1981-1998 & 17 \\
\hline Çankırı & 33.37 & 40.36 & 751 & 1981-1995 & 15 \\
\hline Çorum & 34.58 & 40.33 & 798 & 1981-1998 & 18 \\
\hline Denizli & 29.05 & 37.47 & 428 & 1983-1998 & 16 \\
\hline Diyarbakır & 40.12 & 37.55 & 660 & 1981-1996 & 16 \\
\hline Edirne & 26.34 & 41.40 & 48 & 1983-1998 & 16 \\
\hline Elazığ & 39.13 & 38.40 & 1105 & 1981-1998 & 18 \\
\hline Erzincan & 39.30 & 39.44 & 1215 & 1981-1998 & 18 \\
\hline Erzurum & 41.16 & 39.55 & 1869 & 1983-1998 & 16 \\
\hline Eskişehir & 30.31 & 39.46 & 800 & 1991-1998 & 8 \\
\hline Gaziantep & 37.22 & 37.05 & 855 & 1981-1996 & 16 \\
\hline Giresun & 38.24 & 40.55 & 38 & 1981-1998 & 18 \\
\hline Gümüşhane & 39.27 & 40.27 & 1219 & 1981-1998 & 18 \\
\hline Hakkari & 43.46 & 37.34 & 1720 & 1981-1998 & 18 \\
\hline Hatay & 36.07 & 36.15 & 100 & 1981-1996 & 16 \\
\hline Iğdır & 44.02 & 39.56 & 858 & 1981-1998 & 16 \\
\hline İskenderun & 36.07 & 36.37 & 3 & 1981-1998 & 18 \\
\hline Isparta & 30.33 & 37.45 & 997 & 1981-1998 & 18 \\
\hline İstanbul & 29.05 & 40.58 & 39 & 1981-1996 & 16 \\
\hline İzmir & 27.10 & 38.24 & 25 & 1981-1996 & 16 \\
\hline K.Maraş & 36.56 & 37.36 & 549 & 1983-1998 & 16 \\
\hline Karaman & 33.14 & 37.11 & 1025 & 1981-1998 & 18 \\
\hline Kars & 43.05 & 40.36 & 1775 & 1983-1998 & 16 \\
\hline Kastamonu & 33.46 & 41.22 & 791 & 1981-1998 & 18 \\
\hline Kayseri & 35.29 & 38.43 & 1068 & 1981-1996 & 16 \\
\hline Kilis & 37.05 & 36.44 & 638 & 1981-1998 & 18 \\
\hline
\end{tabular}


Table 1 (continued)

\begin{tabular}{|c|c|c|c|c|c|}
\hline Location & Longitude & Latitude & Elevation (m) & Period & Total years \\
\hline Kırıkkale & 33.30 & 39.50 & 725 & 1981-1995 & 15 \\
\hline Kırklareli & 27.13 & 41.44 & 232 & 1981-1998 & 18 \\
\hline Kırehir & 34.10 & 39.08 & 985 & 1981-1995 & 15 \\
\hline Kocaeli & 29.54 & 40.46 & 76 & 1981-1998 & 18 \\
\hline Konya & 32.30 & 37.52 & 1028 & 1981-1996 & 16 \\
\hline Kütahya & 29.58 & 39.24 & 969 & 1981-1998 & 18 \\
\hline Malatya & 38.18 & 38.21 & 998 & 1983-1998 & 16 \\
\hline Manisa & 27.26 & 38.36 & 71 & 1983-1998 & 16 \\
\hline Mardin & 40.44 & 37.18 & 1080 & 1983-1998 & 16 \\
\hline Mersin & 34.36 & 36.49 & 5 & 1983-1998 & 16 \\
\hline Muğla & 28.21 & 37.12 & 646 & 1981-1996 & 16 \\
\hline Muş & 41.31 & 38.44 & 1283 & 1981-1998 & 18 \\
\hline Nevşehir & 34.40 & 38.25 & 1260 & 1981-1998 & 18 \\
\hline Niğde & 34.40 & 37.59 & 1208 & 1981-1998 & 18 \\
\hline Ordu & 37.52 & 40.59 & 4 & 1981-1998 & 18 \\
\hline Rize & 40.30 & 41.02 & 4 & 1981-1996 & 16 \\
\hline Samsun & 36.20 & 41.17 & 44 & 1981-1996 & 16 \\
\hline Siirt & 41.56 & 37.56 & 875 & 1981-1998 & 18 \\
\hline Sinop & 35.10 & 42.02 & 32 & 1981-1998 & 18 \\
\hline Sivas & 37.01 & 39.49 & 1285 & 1983-1998 & 16 \\
\hline Şanlıurfa & 38.46 & 37.08 & 547 & 1980-1993 & 14 \\
\hline Tekirdağ & 27.29 & 40.59 & 4 & 1983-1998 & 16 \\
\hline Tokat & 36.54 & 40.18 & 608 & 1981-1998 & 18 \\
\hline Trabzon & 39.43 & 41.00 & 30 & 1981-1996 & 16 \\
\hline Tunceli & 39.32 & 39.06 & 979 & 1981-1998 & 18 \\
\hline Uşak & 29.29 & 38.40 & 919 & 1981-1998 & 18 \\
\hline Van & 43.41 & 38.28 & 1725 & 1981-1995 & 15 \\
\hline Yalova & 29.16 & 40.39 & 2 & 1981-1998 & 18 \\
\hline Yozgat & 34.49 & 39.50 & 1298 & 1983-1998 & 16 \\
\hline Zonguldak & 31.48 & 41.27 & 136 & 1981-1998 & 18 \\
\hline
\end{tabular}

\subsection{Annual heating degree-days}

Table 2 shows the annual heating degree-days with $14,16,18,20$, and $22^{\circ} \mathrm{C}$ base temperatures. As can be seen from Table 2, significant differences between the values of heating degree-days for different locations are evident for the same base temperature. For example, the annual heating degree-days for İskenderun (located in the east Mediterranean) is 690, while it is 5137 for Ardahan (located in the northeast), at a base temperature of $18^{\circ} \mathrm{C}$. This shows that a building in Ardahan needs 7.44 times more heating energy than a building located in İskenderun, both having the same characteristics.

Fig. 1 shows variation of the annual heating degree-days with base temperature for the main provinces of Turkey. The heating degree-days increase almost linearly with increasing base temperature. Increasing base temperature from the traditionally accepted value of 18 to $20^{\circ} \mathrm{C}$ results in approximately $14 \%$ higher heating degreedays in Erzurum, whilst the increase is about $40 \%$ for Adana. Therefore, thermal 
Table 2

The annual heating degree-days for Turkey

\begin{tabular}{|c|c|c|c|c|c|}
\hline \multirow[b]{2}{*}{ Province } & \multicolumn{5}{|c|}{ Base temperature $\left({ }^{\circ} \mathrm{C}\right)$} \\
\hline & 14 & 16 & 18 & 20 & 22 \\
\hline Adana & 341 & 579 & 874 & 1220 & 1610 \\
\hline Adapazarı & 1049 & 1413 & 1833 & 2309 & 2862 \\
\hline Adiyaman & 995 & 1328 & 1695 & 2094 & 2527 \\
\hline Afyon & 1878 & 2325 & 2828 & 3395 & 4025 \\
\hline Ağr1 & 3353 & 3867 & 4423 & 5031 & 5692 \\
\hline Aksaray & 1743 & 2157 & 2626 & 3153 & 3738 \\
\hline Amasya & 1393 & 1778 & 2210 & 2700 & 3256 \\
\hline Ankara & 1773 & 2199 & 2677 & 3214 & 3811 \\
\hline Antalya & 439 & 731 & 1083 & 1481 & 1926 \\
\hline Ardahan & 3861 & 4469 & 5137 & 5845 & 6571 \\
\hline Artvin & 1535 & 1951 & 2429 & 2983 & 3619 \\
\hline Aydin & 580 & 867 & 1213 & 1603 & 2037 \\
\hline Balıkesir & 1128 & 1498 & 1914 & 2381 & 2907 \\
\hline Bartın & 1330 & 1747 & 2226 & 2777 & 3403 \\
\hline Batman & 1117 & 1450 & 1823 & 2235 & 2683 \\
\hline Bayburt & 3006 & 3545 & 4149 & 4807 & 5510 \\
\hline Bilecik & 1521 & 1933 & 2397 & 2922 & 3517 \\
\hline Bingöl & 1994 & 2399 & 2838 & 3319 & 3848 \\
\hline Bitlis & 2340 & 2800 & 3311 & 3863 & 4473 \\
\hline Bolu & 1832 & 2291 & 2821 & 3423 & 4091 \\
\hline Burdur & 1496 & 1902 & 2351 & 2848 & 3406 \\
\hline Bursa & 1117 & 1491 & 1920 & 2401 & 2948 \\
\hline Çanakkale & 1003 & 1371 & 1789 & 2258 & 2782 \\
\hline Çankırı & 1928 & 2370 & 2864 & 3418 & 4035 \\
\hline Çorum & 1965 & 2428 & 2958 & 3563 & 4234 \\
\hline Denizli & 907 & 1245 & 1627 & 2052 & 2520 \\
\hline Diyarbakır & 1375 & 1739 & 2142 & 2583 & 3057 \\
\hline Edirne & 1403 & 1791 & 2224 & 2708 & 3250 \\
\hline Elazığ & 1805 & 2211 & 2653 & 3135 & 3662 \\
\hline Erzincan & 2129 & 2564 & 3047 & 3577 & 4164 \\
\hline Erzurum & 3637 & 4205 & 4827 & 5499 & 6207 \\
\hline Eskişehir & 2043 & 2516 & 3049 & 3649 & 4310 \\
\hline Gaziantep & 1242 & 1605 & 2009 & 2450 & 2926 \\
\hline Giresun & 957 & 1328 & 1765 & 2263 & 2830 \\
\hline Gümüşhane & 2228 & 2702 & 3234 & 3832 & 4492 \\
\hline Hakkari & 2543 & 2986 & 3470 & 3997 & 4564 \\
\hline Hatay & 528 & 797 & 1119 & 1489 & 1906 \\
\hline Iğdır & 1914 & 2319 & 2764 & 3256 & 3792 \\
\hline İskenderun & 218 & 420 & 690 & 1022 & 1406 \\
\hline Isparta & 1684 & 2120 & 2607 & 3156 & 3763 \\
\hline İstanbul & 1054 & 1433 & 1865 & 2350 & 2897 \\
\hline İzmir & 562 & 845 & 1188 & 1583 & 2023 \\
\hline K. Maraş & 954 & 1284 & 1653 & 2059 & 2500 \\
\hline Karaman & 1809 & 2229 & 2698 & 3222 & 3809 \\
\hline Kars & 3573 & 4145 & 4772 & 5451 & 6168 \\
\hline Kastamonu & 2088 & 2567 & 3112 & 3726 & 4402 \\
\hline
\end{tabular}


Table 2 (continued)

\begin{tabular}{|c|c|c|c|c|c|}
\hline \multirow[b]{2}{*}{ Province } & \multicolumn{5}{|c|}{ Base temperature $\left({ }^{\circ} \mathrm{C}\right)$} \\
\hline & 14 & 16 & 18 & 20 & 22 \\
\hline Kayseri & 2120 & 2587 & 3113 & 3704 & 4359 \\
\hline Kilis & 877 & 1196 & 1554 & 1948 & 2372 \\
\hline Kırıkkale & 1731 & 2145 & 2609 & 3129 & 3711 \\
\hline Kirklareli & 1429 & 1828 & 2274 & 2770 & 3326 \\
\hline Kırşehir & 1923 & 2365 & 2857 & 3404 & 4018 \\
\hline Kocaeli & 1015 & 1375 & 1786 & 2257 & 2790 \\
\hline Konya & 1916 & 2350 & 2836 & 3371 & 3968 \\
\hline Kütahya & 1899 & 2360 & 2880 & 3469 & 4120 \\
\hline Malatya & 1648 & 2037 & 2461 & 2923 & 3431 \\
\hline Manisa & 843 & 1166 & 1535 & 1947 & 2400 \\
\hline Mardin & 1270 & 1621 & 2004 & 2421 & 2869 \\
\hline Mersin & 311 & 552 & 852 & 1211 & 1622 \\
\hline Muğla & 1081 & 1458 & 1879 & 2339 & 2847 \\
\hline Muş & 2656 & 3088 & 3563 & 4082 & 4647 \\
\hline Nevşehir & 2044 & 2508 & 3033 & 3626 & 4281 \\
\hline Niğde & 1922 & 2362 & 2856 & 3414 & 4038 \\
\hline Ordu & 984 & 1361 & 1804 & 2303 & 2869 \\
\hline Rize & 991 & 1375 & 1820 & 2331 & 2912 \\
\hline Samsun & 996 & 1377 & 1826 & 2339 & 2926 \\
\hline Siirt & 1230 & 1577 & 1958 & 2374 & 2826 \\
\hline Sinop & 1038 & 1430 & 1879 & 2390 & 2969 \\
\hline Sivas & 2412 & 2896 & 3444 & 4061 & 4732 \\
\hline Şanlıurfa & 852 & 1157 & 1503 & 1885 & 2303 \\
\hline Tekirdağ & 1193 & 1586 & 2032 & 2531 & 3098 \\
\hline Tokat & 1534 & 1938 & 2399 & 2922 & 3516 \\
\hline Trabzon & 923 & 1291 & 1724 & 2223 & 2800 \\
\hline Tunceli & 1880 & 2280 & 2716 & 3198 & 3727 \\
\hline Uşak & 1525 & 1945 & 2414 & 2939 & 3526 \\
\hline Van & 2454 & 2938 & 3476 & 4069 & 4721 \\
\hline Yalova & 1033 & 1409 & 1843 & 2340 & 2903 \\
\hline Yozgat & 2350 & 2853 & 3422 & 4057 & 4743 \\
\hline Zonguldak & 1162 & 1557 & 2020 & 2557 & 3181 \\
\hline
\end{tabular}

characteristics of the building and preferences of the occupants should be changed to lower the base temperature if possible. To lower the base temperature, thermostat settings should be reduced to the lower end of the comfort region, thermal insulation should be applied to buildings and air leakages should be minimised. Another factor that affects the value of the base temperature is the solar gain. Buildings should be constructed in such a way that they receive the maximum possible solar radiation during heating season and the minimum during cooling season. A reduction in base temperature from 18 to $16^{\circ} \mathrm{C}$ lowers the heating-degree days by approximately $13 \%$ in Erzurum and $34 \%$ in Adana.

A counter map of the annual heating degree-days for an $18^{\circ} \mathrm{C}$ base temperature is depicted in Fig. 2. The figure shows clearly the non-uniformity of climate of Turkey. For locations near to sea coasts, the heating degree-days have lower values compared with the eastern and the inner regions. The higher degree-days appear in the 


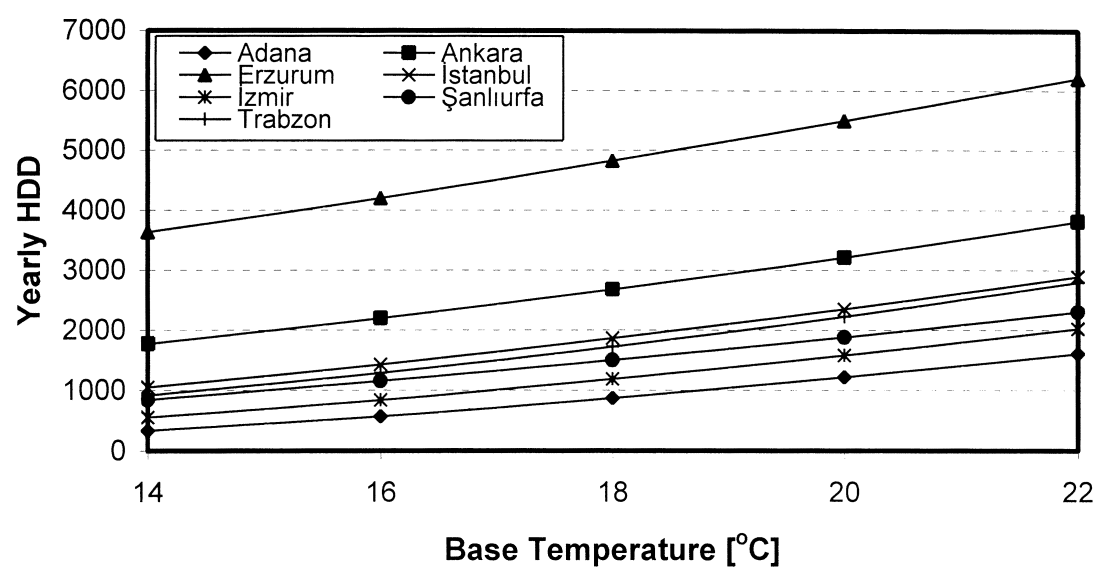

Fig. 1. Variation of yearly heating degree-days with base temperature for the main provinces of Turkey.

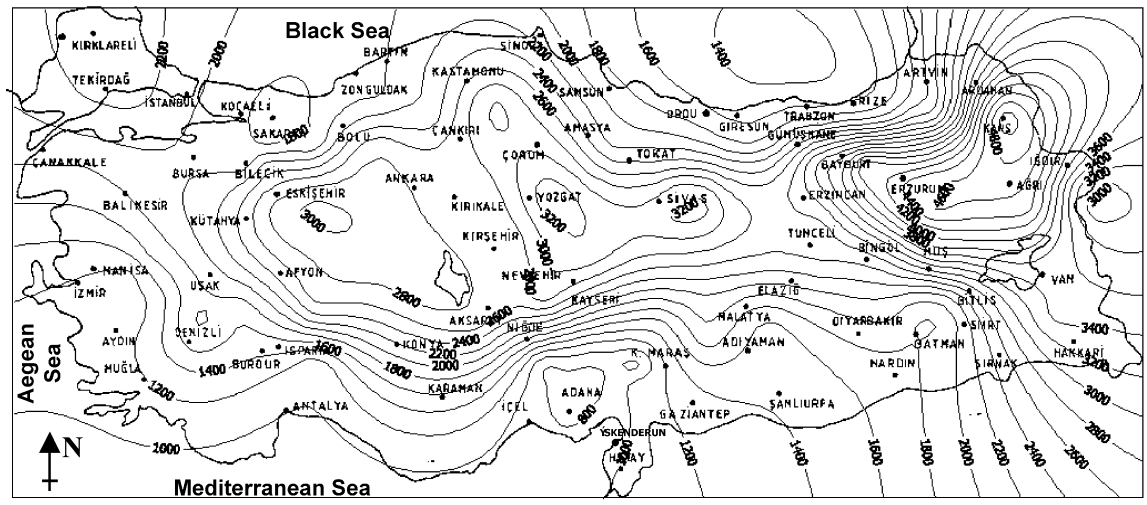

Fig. 2. The counter map of yearly heating degree-days for an $18^{\circ} \mathrm{C}$ base temperature in Turkey.

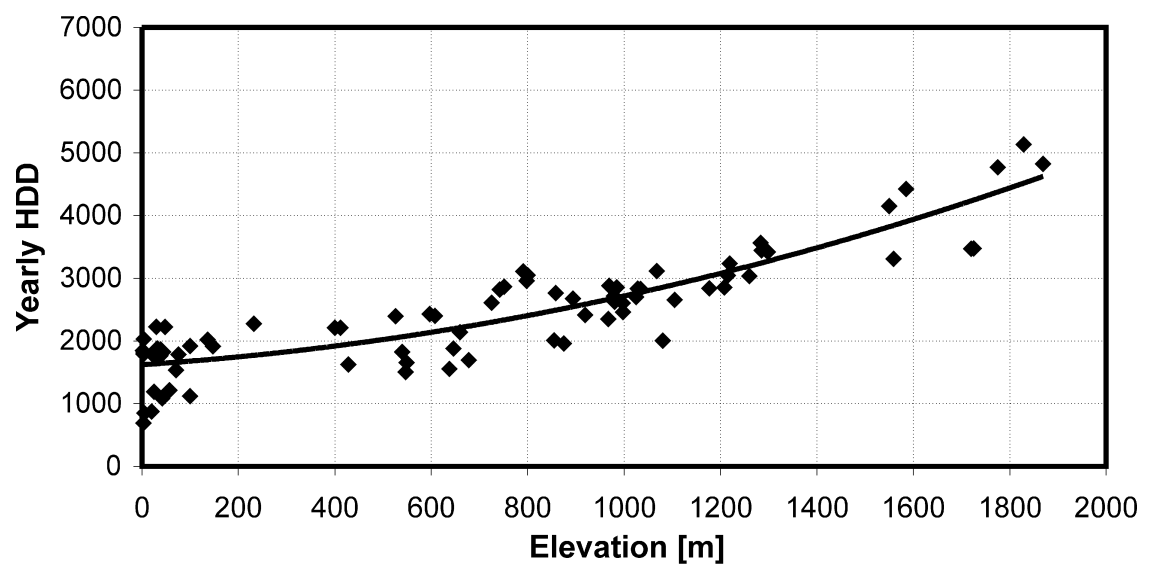

Fig. 3. Variation of yearly heating degree-days with elevation above sea level for Turkey. 
eastern and northeastern Turkey. The counters are close to each other in the lower part of the inner region (around Niğde), in the east and in the northeast. This shows a rapid climate change within short distances due to mountainous nature of the landscape in these regions.

The landscape of Turkey, which contains large plains, high plateaus, high mountains and mountain chains, is quite non-uniform. Elevation of the cities varies between zero and $1869 \mathrm{~m}$. A correlation between the heating degree-days and elevation is evident from Fig. 3. The value of the heating degree-days increases with elevation.

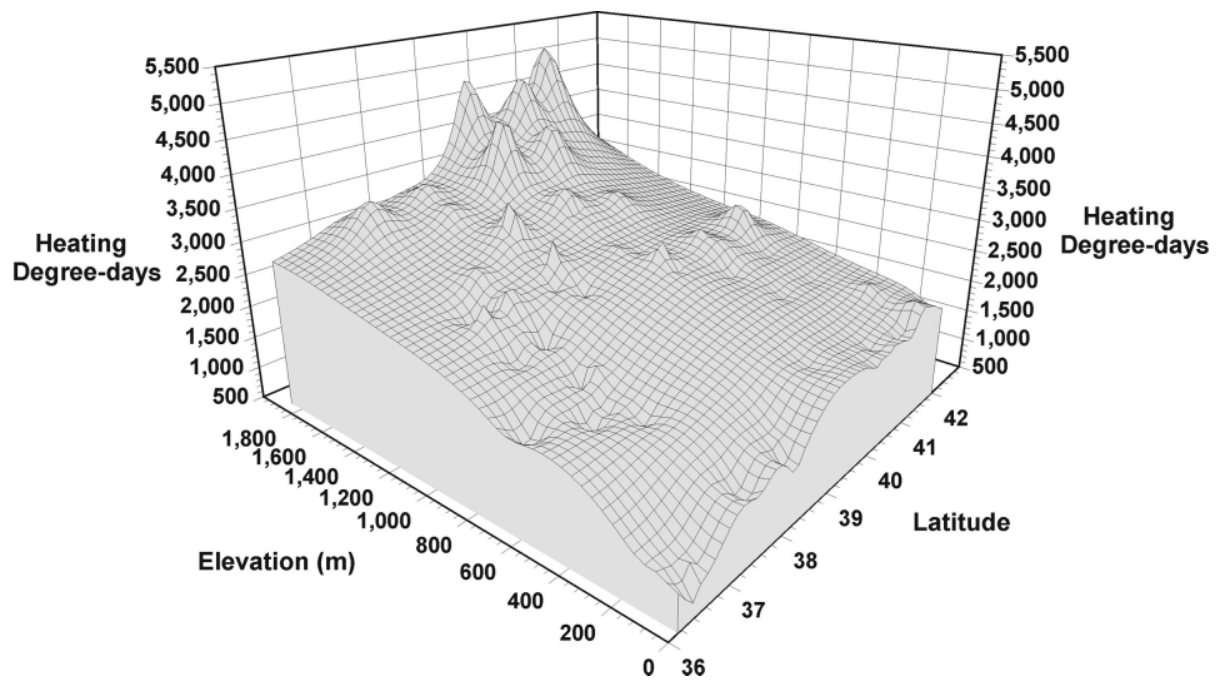

Fig. 4. Variation of yearly heating degree-days with elevation and latitude for Turkey.

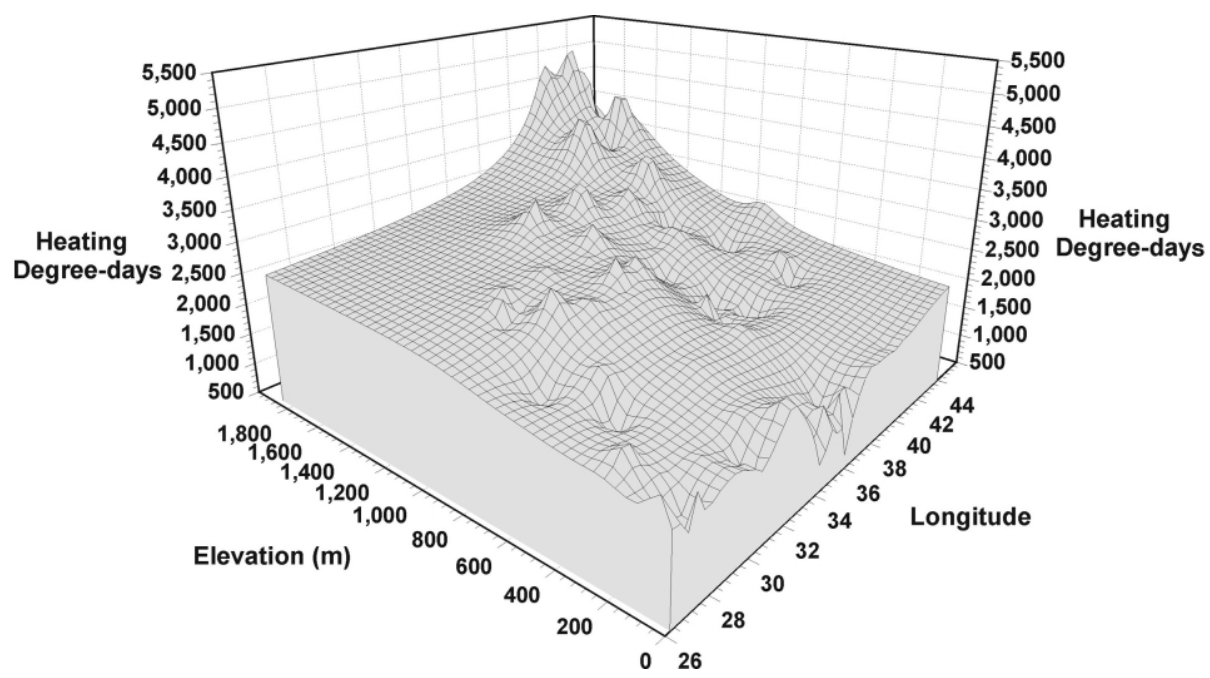

Fig. 5. Variation of early heating degree-days with elevation and longitude for Turkey. 
Table 3

The annual cooling degree-days for Turkey

\begin{tabular}{|c|c|c|c|c|c|c|}
\hline \multirow[b]{2}{*}{ Province } & \multicolumn{6}{|c|}{ Base temperature $\left({ }^{\circ} \mathrm{C}\right)$} \\
\hline & 18 & 20 & 22 & 24 & 26 & 28 \\
\hline Adana & 1520 & 1136 & 796 & 500 & 255 & 82 \\
\hline Adapazarı & 585 & 333 & 155 & 51 & 10 & 1 \\
\hline Adiyaman & 1451 & 1122 & 824 & 570 & 360 & 198 \\
\hline Afyon & 321 & 156 & 58 & 14 & 2 & 0 \\
\hline A ̌̆r1 & 226 & 104 & 35 & 9 & 1 & 0 \\
\hline Aksaray & 479 & 273 & 131 & 47 & 11 & 2 \\
\hline Amasya & 574 & 331 & 159 & 57 & 14 & 2 \\
\hline Ankara & 433 & 240 & 109 & 37 & 8 & 1 \\
\hline Antalya & 1178 & 846 & 562 & 330 & 164 & 68 \\
\hline Ardahan & 25 & 4 & 0 & 0 & 0 & 0 \\
\hline Artvin & 329 & 154 & 58 & 19 & 5 & 0 \\
\hline Aydin & 1234 & 895 & 601 & 355 & 170 & 55 \\
\hline Balıkesir & 695 & 432 & 226 & 91 & 20 & 4 \\
\hline Bartın & 327 & 149 & 44 & 9 & 1 & 0 \\
\hline Batman & 1364 & 1044 & 763 & 519 & 318 & 163 \\
\hline Bayburt & 106 & 36 & 8 & 1 & 0 & 0 \\
\hline Bilecik & 442 & 238 & 101 & 33 & 7 & 1 \\
\hline Bingöl & 811 & 562 & 361 & 197 & 83 & 21 \\
\hline Bitlis & 402 & 224 & 105 & 35 & 6 & 0 \\
\hline Bolu & 213 & 85 & 22 & 4 & 0 & 0 \\
\hline Burdur & 586 & 355 & 183 & 71 & 14 & 1 \\
\hline Bursa & 606 & 359 & 177 & 61 & 12 & 2 \\
\hline Çanakkale & 717 & 455 & 249 & 103 & 25 & 4 \\
\hline Çankırı & 364 & 190 & 76 & 22 & 4 & 0 \\
\hline Çorum & 211 & 84 & 24 & 4 & 0 & 0 \\
\hline Denizli & 1036 & 730 & 469 & 265 & 120 & 36 \\
\hline Diyarbakır & 1185 & 896 & 640 & 422 & 242 & 113 \\
\hline Edirne & 629 & 381 & 195 & 72 & 16 & 3 \\
\hline Elazığ & 790 & 543 & 337 & 179 & 75 & 19 \\
\hline Erzincan & 470 & 274 & 130 & 44 & 8 & 0 \\
\hline Erzurum & 88 & 30 & 7 & 1 & 0 & 0 \\
\hline Eskişehir & 226 & 93 & 27 & 4 & 0 & 0 \\
\hline Gaziantep & 1061 & 774 & 521 & 312 & 157 & 56 \\
\hline Giresun & 501 & 271 & 108 & 23 & 3 & 0 \\
\hline Gümüşhane & 243 & 111 & 40 & 9 & 2 & 0 \\
\hline Hakkari & 549 & 345 & 184 & 72 & 18 & 2 \\
\hline Hatay & 1288 & 929 & 614 & 348 & 139 & 24 \\
\hline Iğdır & 711 & 471 & 276 & 132 & 43 & 7 \\
\hline İskenderun & 1433 & 1033 & 687 & 398 & 175 & 40 \\
\hline Isparta & 392 & 210 & 88 & 23 & 4 & 0 \\
\hline İstanbul & 588 & 342 & 159 & 47 & 6 & 0 \\
\hline İzmir & 1182 & 847 & 559 & 319 & 147 & 44 \\
\hline K. Maraş & 1262 & 937 & 649 & 405 & 210 & 80 \\
\hline Karaman & 468 & 262 & 119 & 39 & 7 & 0 \\
\hline Kars & 67 & 17 & 2 & 0 & 0 & 0 \\
\hline Kastamonu & 193 & 79 & 23 & 4 & 0 & 0 \\
\hline
\end{tabular}


Table 3 (continued)

\begin{tabular}{|c|c|c|c|c|c|c|}
\hline \multirow[b]{2}{*}{ Province } & \multicolumn{6}{|c|}{ Base temperature $\left({ }^{\circ} \mathrm{C}\right)$} \\
\hline & 18 & 20 & 22 & 24 & 26 & 28 \\
\hline Kayseri & 251 & 112 & 38 & 8 & 1 & 0 \\
\hline Kilis & 1329 & 992 & 689 & 429 & 224 & 89 \\
\hline Kırıkkale & 487 & 276 & 128 & 43 & 10 & 1 \\
\hline Kirklareli & 592 & 358 & 185 & 72 & 20 & 6 \\
\hline Kırşehir & 383 & 202 & 85 & 24 & 4 & 0 \\
\hline Kocaeli & 665 & 404 & 204 & 76 & 18 & 2 \\
\hline Konya & 424 & 232 & 101 & 31 & 5 & 0 \\
\hline Kütahya & 251 & 110 & 35 & 7 & 0 & 0 \\
\hline Malatya & 897 & 629 & 407 & 229 & 103 & 33 \\
\hline Manisa & 1164 & 844 & 570 & 343 & 171 & 62 \\
\hline Mardin & 1353 & 1037 & 755 & 515 & 315 & 161 \\
\hline Mersin & 1279 & 907 & 585 & 317 & 124 & 20 \\
\hline Muğla & 861 & 592 & 369 & 198 & 81 & 22 \\
\hline Muş & 584 & 373 & 208 & 92 & 25 & 3 \\
\hline Nevşehir & 259 & 121 & 47 & 13 & 2 & 0 \\
\hline Niğde & 342 & 168 & 63 & 14 & 2 & 0 \\
\hline Ordu & 512 & 284 & 119 & 30 & 3 & 0 \\
\hline Rize & 452 & 228 & 81 & 13 & 1 & 0 \\
\hline Samsun & 438 & 219 & 76 & 11 & 0 & 0 \\
\hline Siirt & 1341 & 1026 & 747 & 509 & 311 & 158 \\
\hline Sinop & 460 & 242 & 92 & 16 & 1 & 0 \\
\hline Sivas & 196 & 82 & 27 & 6 & 1 & 0 \\
\hline Şanlıurfa & 1601 & 1254 & 940 & 665 & 429 & 243 \\
\hline Tekirdağ & 504 & 272 & 112 & 26 & 3 & 0 \\
\hline Tokat & 439 & 234 & 97 & 30 & 5 & 0 \\
\hline Trabzon & 476 & 245 & 91 & 17 & 1 & 0 \\
\hline Tunceli & 804 & 555 & 353 & 193 & 85 & 24 \\
\hline Uşak & 475 & 270 & 127 & 43 & 9 & 0 \\
\hline Van & 248 & 109 & 32 & 6 & 1 & 0 \\
\hline Yalova & 524 & 289 & 123 & 32 & 4 & 0 \\
\hline Yozgat & 160 & 63 & 20 & 4 & 0 & 0 \\
\hline Zonguldak & 350 & 157 & 50 & 14 & 2 & 0 \\
\hline
\end{tabular}

The scatter is mainly due to the effects of latitude and longitude. The combined influences on heating degree-days of elevation and latitude and of elevation and longitude are shown in the form of three-dimensional graphs in Figs. 4 and 5, respectively. It is clear from Fig. 4 that, heating degree-days are generally higher when both elevation and latitude are high, although there are some non-uniformities. They are quite small at the opposite corner (where both elevation and latitude are low). Fig. 5 shows the combined influences of elevation and longitude. The value of heating degree-days is generally higher for the regions having a high elevation and a high longitude.

\subsection{Annual cooling degree-days}

The annual cooling degree-days for base temperatures of 18, 20, 22, 24, 26 and $28^{\circ} \mathrm{C}$ for 78 provinces of Turkey are given in Table 3. Analysis of Table 3 reveals 
that there are significant differences between the values of cooling degree-days for different provinces at the same base temperature. Whilst there is no need for cooling in Ardahan (located in the northeast) for which the value of the cooling degree-day is zero, the cooling requirement is a maximum for Şanliurfa (located in the southeast) with a cooling degree-day value of 940 at a $22^{\circ} \mathrm{C}$ base temperature.

The value of cooling degree-days increases significantly with the decrease of base temperature (Fig. 6). Therefore, thermal characteristics of the building and preferences of the occupants should be changed to increase the base temperature if possible. Increasing the base temperature above the traditionally used base temperature of $22^{\circ} \mathrm{C}$ diminishes the need for cooling completely for some provinces (such as Kars, Çorum, Kütahya, Niğde, and Samsun). However, significant cooling is still required for some cities, especially for those located in the south and the southeast Turkey. Increasing the base temperature from 22 to $24^{\circ} \mathrm{C}$ results in approximately $29 \%$ lower cooling degree-

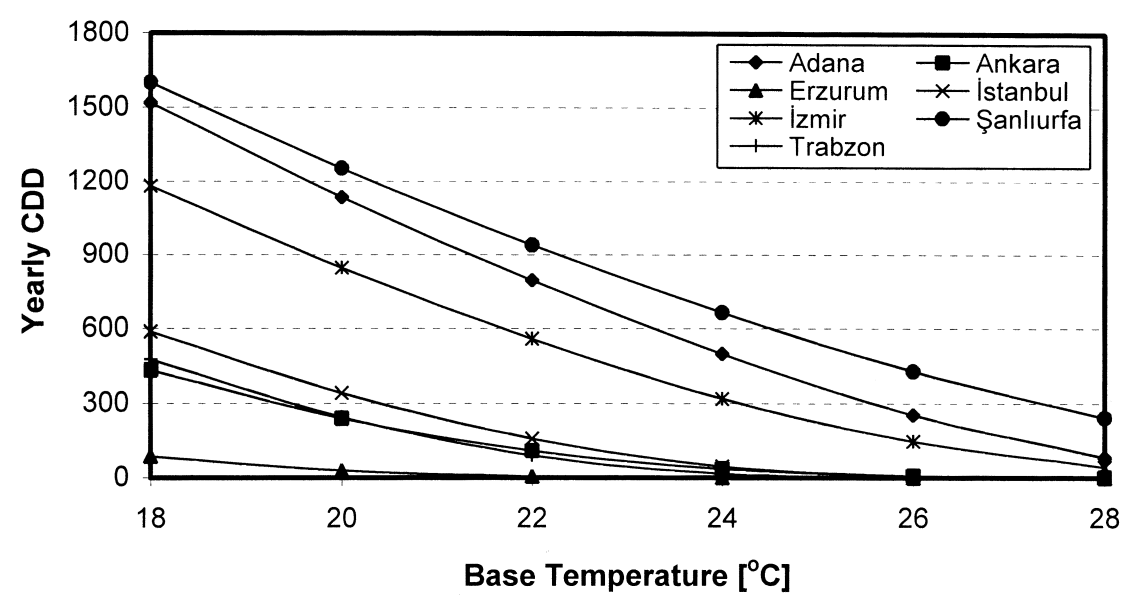

Fig. 6. Variation of yearly cooling degree-days with base temperature for the main provinces of Turkey.

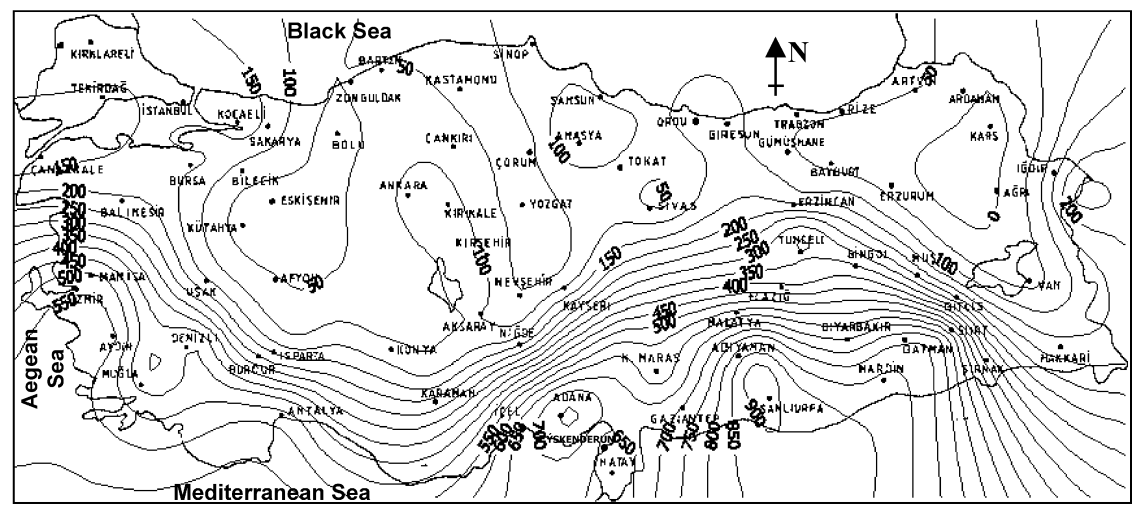

Fig. 7. The counter map of yearly cooling degree-days at a $22^{\circ} \mathrm{C}$ base temperature for Turkey. 
days in Şanluurfa. The increase in cooling degree days is at the same level (approximately $33 \%$ ), when the base temperature is changed from 22 down to $20^{\circ} \mathrm{C}$.

Fig. 7 shows a counter map of the yearly cooling degree-days at $22^{\circ} \mathrm{C}$ base temperature for Turkey. As can be seen from the figure, the cooling requirement is essentially zero in the north, northeastern, eastern and the inner regions of Turkey. However, a substantial amount of cooling is needed in the south and southeast Turkey. The counters are close to each other between Adana and Niğde (around Niğde), and in the east.

The correlation observed between elevation and the heating degree-days does not exist in the case of cooling-degree days (Fig. 8). However, combined influence of elevation and latitude on the cooling degree-days is clear from Fig. 9. For the provinces

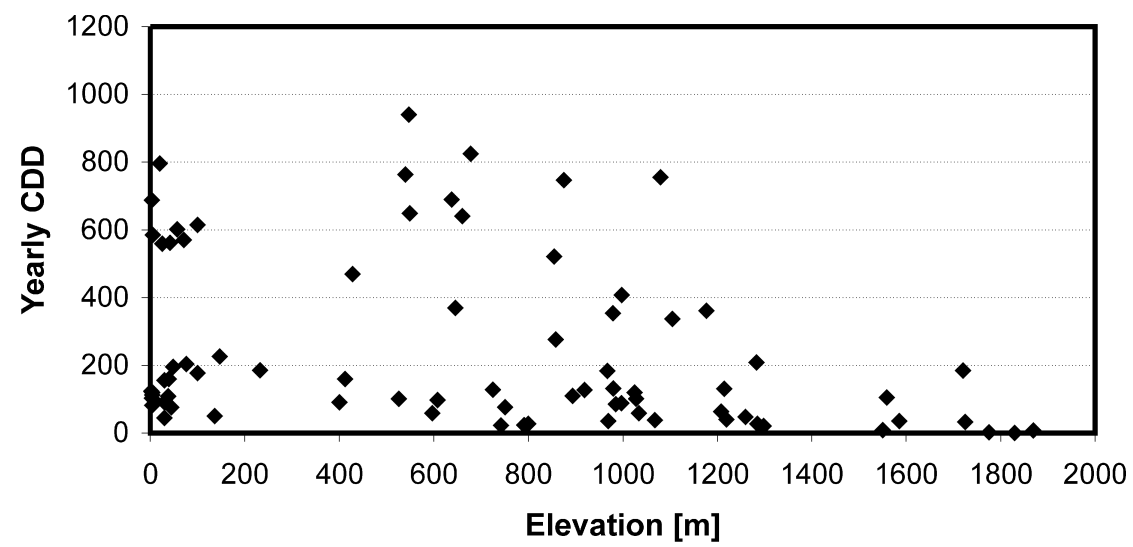

Fig. 8. Variation of yearly cooling degree-days with elevation for Turkey.

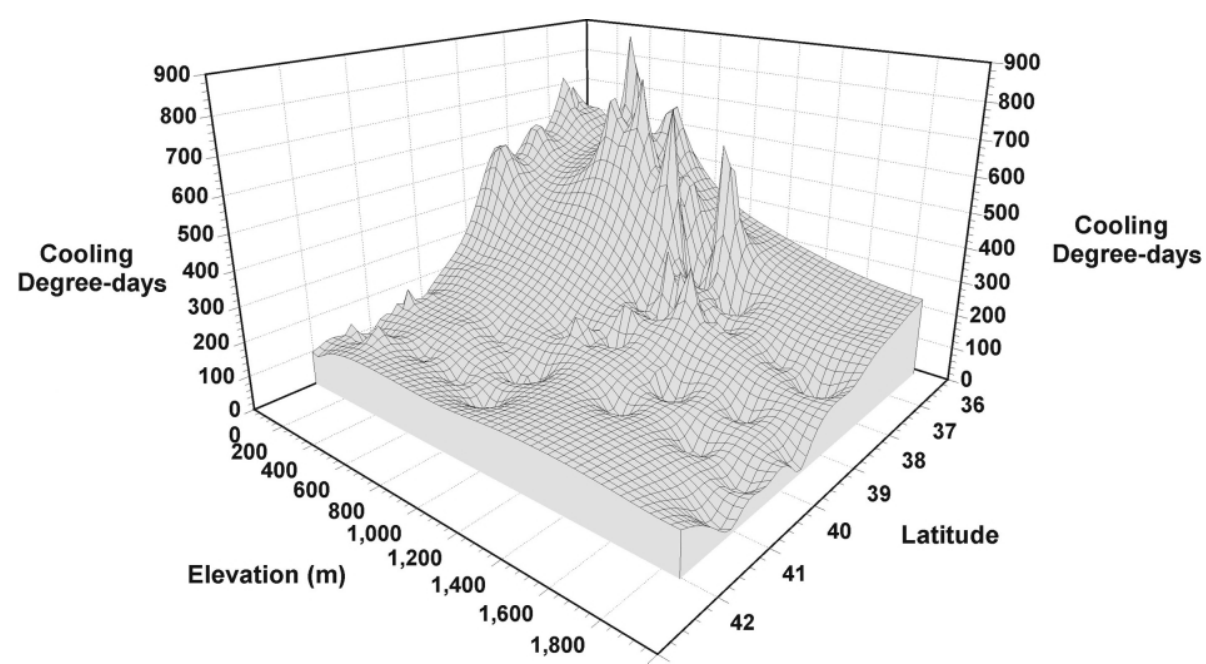

Fig. 9. Variation of yearly cooling degree-days with elevation and latitude for Turkey. 


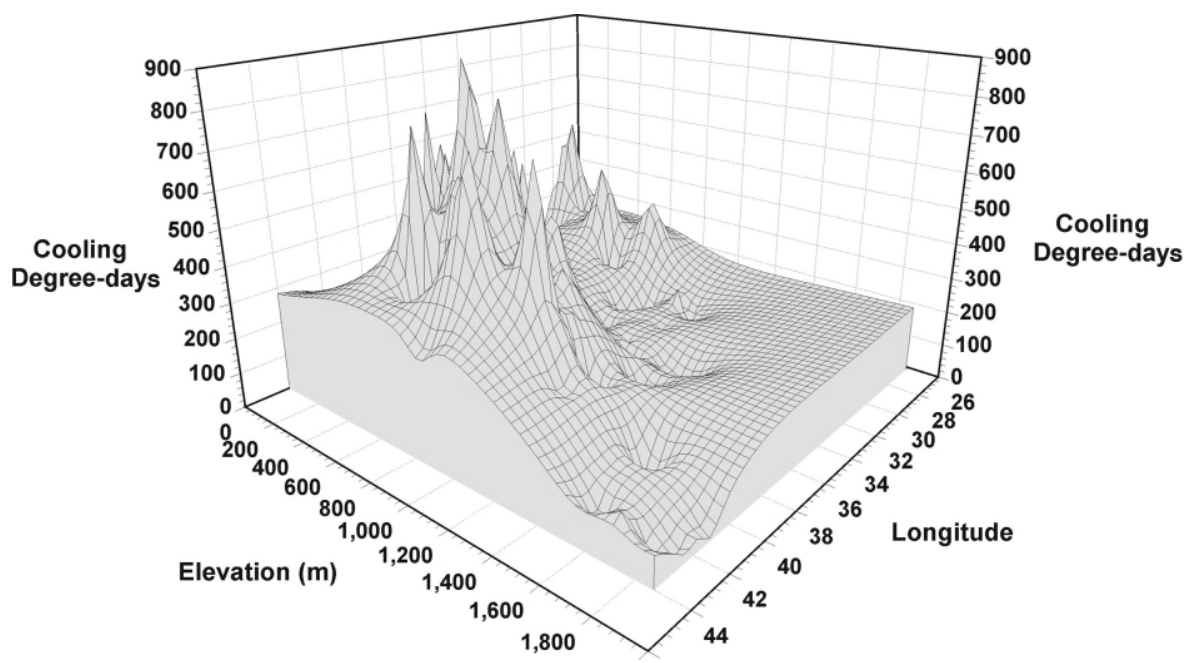

Fig. 10. Variation of yearly cooling degree-days with elevation and longitude for Turkey.

having elevations less than $1100 \mathrm{~m}$ and located in the south (where the latitude is less than $39^{\circ}$ ), cooling is a necessity. The value of the cooling-degree days is generally smaller than 200 at high elevations $(>1100 \mathrm{~m})$. This is also the case for the northern part of Turkey (latitude $>40^{\circ}$ ).

The combined influence of elevation and longitude on the cooling degree-days (Fig. 10) is not as clear as in the case of elevation and latitude.

\section{Conclusions}

The heating and cooling degree-days with variable-base temperatures for Turkey are determined using long-term measured data. Base temperatures of 14, 16, 18, 20, and $22^{\circ} \mathrm{C}$ are chosen in the calculation of heating degree-days. Base temperatures of $18,20,22,24,26$ or $28^{\circ} \mathrm{C}$ are used in the determination of cooling degree-days. Yearly heating and cooling degree-days are given in tabular forms for all the provinces of Turkey. The cooling and the heating degree-days are also presented on the counter maps. The values of both heating and cooling degree-days exhibit big fluctuations throughout Turkey. While the northeastern and the inner regions of Turkey require comparatively more heating energy, they need less or no cooling.

\section{Acknowledgements}

The authors wish to express their gratitude to The State Meteorological Affairs General Directorate (DMİ) for providing the meteorological data. 


\section{References}

[1] ASHRAE Handbook - Fundamentals (SI). Energy Estimating Methods (chapter 28) 1993.

[2] Said SAM. Degree-day base temperature for residential building energy prediction in Saudi Arabia. ASHRAE Transactions 1992;98(1):346-53.

[3] Kreider JF, Rabl A. Heating and cooling of buildings. New York: McGraw Hill, 1994.

[4] Kodah ZH, El-Shaarawi MAI. Weather data in Jordan for conventional and solar HVAC systems. ASHRAE Transactions 1990;96(1):124-31.

[5] Badescu V, Zamfir E. Degree-days, degree-hours and ambient temperature bin data from monthlyaverage temperatures (in Romania). Energy Conversion and Management 1999;40:885-900.

[6] Satman A, Yalcinkaya N. Heating and cooling degree-hours for Turkey. Energy 1999;24:833-40.

[7] Dağsöz AK, Bayraktar KG. The number of degree-day in Turkey and energy politics Journal of Sanitary Engineering 1999; July-August: 32-40 (in Turkish).

[8] Büyükalaca O, Bulut H, Yılmaz T. Degree-days values for some provinces of Turkey — Conference Proceeding of 12 th Turkish National Conference on Thermal Sciences and Technologies with International Participation, Sakarya, Turkey, vol. 1, pp. 107-12, 2000 (in Turkish).

[9] Uner M, Ileri A. Typical weather data of main Turkish cities for energy applications. International Journal of Energy Research 2000;24(8):727-48.

[10] Kadıoglu M, Şen Z. Degree day formulations and application in Turkey. Journal of Applied Meteorology 1999;38:837-46. 